\section{PHYSICS AND CHEMISTRY OF SOLID STATE \\ V. 21, N 1 (2020) p. 82-88}

DOI: 10.15330/pcss.21.1.82-88
Vasyl Stefanyk Precarpathian

National University

ФІЗИКА І ХІМІЯ ТВЕРДОГО ТІЛА

T. 21, № 1 (2020) C. 82-88

Ya.P. Saliy, O.M. Matkivskyi, I.V. Horichok

\title{
Scattering Mechanisms in pressed PbTe
}

\author{
Vasyl Stefanyk Precarpathian National University, Ivano-Frankivsk, Ukraine, e-mail: o.matkivsky@opora.org.ua
}

\begin{abstract}
The results of studies of structural and thermoelectric properties obtained by the powder pressing method of $\mathrm{PbTe}$ samples are presented. In order to interpret the obtained results, a theoretical calculation of the specific conductivity and the Seebeck coefficient was performed on the basis of a model that takes into account two types of free charge carriers. Conclusions have been made about the mechanisms of carrier scattering.

Keywords: plumbum telluride, thermoelectric properties, scattering mechanisms.
\end{abstract}

Received 03.03.2020; accepted for publication 15.03.2020.

\section{Introduction}

Lead semiconductor material $\mathrm{A}^{4} \mathrm{~B}^{6}$ is used to create thermoelectric modules operating in the $200-500^{\circ} \mathrm{C}$ temperature range [1-4]. Analysis of published data shows that alternative materials that are less effective or much more expensive. Therefore, modification of the properties of $\mathrm{PbTe}$ to improve its thermoelectric parameters remains urgent task.

Preferably, PbTe obtained by pressing the powder is used to create thermocouples. Given the correct choice of technological parameters of obtaining such a material has several advantages over single crystalline, in particular, improved mechanical properties. However, the pressing process itself, the influence of its individual stages on the properties of the material are poorly understood. Such information can be used to optimize the technological factors of obtaining a material and to increase its thermoelectric figure of merit.

In articles [6-7], PbTe samples were obtained by cold pressing at $2 \mathrm{GPa}$. It is shown that the samples obtained at room temperatures are characterized by a ptype of conductivity, which changes with n-type with increasing temperature due to the manifestation of its own conductivity with the predominance of the electronic component. The p-type conductivity of the material at low temperatures is explained by the interaction of the material with oxygen, since some technological operations took place in the air [7]. It has been established that annealing of the samples at $500{ }^{\circ} \mathrm{C}$ leads to recrystallization of the samples, which causes, in particular, an increase in their specific electrical conductivity. It should be noted that the parameter of the elementary cell of the material changes during the operations within the error, as well as the Hall concentration of carriers [6]. Thus, it can be assumed that the defective subsystem of samples does not change during technological operations, and the modification of thermoelectric parameters is caused only by recrystallization of grains.

The analysis of the obtained experimental dependences [6] was performed in [7]. In particular, it is shown that scattering on acoustic phonons is decisive in the formation of kinetic properties of current carriers (heavy holes) in the samples at temperatures up to $200{ }^{\circ} \mathrm{C}$. Under certain technological conditions of sample preparation, the effect of thermoelectronic emission of carriers between grains on their kinetic properties is also possible. The conclusion drawn in [7] is partly consistent with the literature data. Thus, [8] found that light holes scatter on acoustic and polar optical phonons, while heavy holes only scatter on acoustic phonons. According to [8], in particular, the electrons in the temperature range $77-300 \mathrm{~K}$ are mainly scattered on the acoustic vibrations of the lattice [9]. The additional analysis thus requires the influence of thermoelectronic emission of carriers between grains, since the temperature range studied is relatively high, as for the manifestation of this mechanism.

The purpose of this work is a consistent theoretical analysis of the temperature dependences of the specific 
electrical conductivity and the Seebeck coefficient for the samples described in $[6,7]$ and new ones obtained under other technological conditions.

\section{Methods of experimental research}

The complex of studies was performed for the samples obtained by cold pressing in air at pressure $(1.5 \mathrm{GPa}$ and $2.0 \mathrm{GPa})$ and hot pressing $\left(\mathrm{T}=250^{\circ} \mathrm{C}\right)$ in argon at a pressure of $0,5 \mathrm{GPa}$, followed by annealing of the pressed samples at $\mathrm{T}=500{ }^{\circ} \mathrm{C}$.

PbTe synthesis was carried out according to the following scheme: heating the charge to $500{ }^{\circ} \mathrm{C}$ for $0.5 \mathrm{~h}$ (holding $1 \mathrm{~h}$ ), heating to $700{ }^{\circ} \mathrm{C}$ for $0.5 \mathrm{~h}$ (holding $3 \mathrm{~h}$ ), heating to $1020{ }^{\circ} \mathrm{C}$ for $0.5 \mathrm{~h}$ (holding $1 \mathrm{~h}$ ), cooling to $900{ }^{\circ} \mathrm{C}$ for $0.5 \mathrm{~h}$, cooling outside the oven. AlfaAesar tellurium and lead (manufactured by Germany) were used for the synthesis. The content of the basic substance is the Te 99.999 wt. \%, and $\mathrm{Pb}-99.99$ wt. \%.

The resulting ingots were ground in a Pulverisette 6 automatic mill and fractions $(0.05-0,5) \mathrm{mm}$ were selected for sample production on the AS200 screening machine.

Techniques for studying structural thermoelectric properties are described in detail in [6].

\section{Research results and their analysis}

The synthesized ingots were characterized by a bright metallic luster, without visible macrodefects (Figs. 1a, 1b). Samples for measurements of electrophysical parameters were extruded from fractions $(0.05-0.5) \mathrm{mm}$. From the analysis of micrographs of the surface of the ingots, it can be stated that grains of this size are most likely to be monoblocked with a small amount of crystallites.

On the basis of SEM studies, the effect of recrystallization of the pressed sample upon annealing at $500{ }^{\circ} \mathrm{C}$ was confirmed (Fig. 1c, 1d). The density of pressed 1.5 GPa samples is slightly lower than in the case of samples pressed at a pressure of $2 \mathrm{GPa}$ [7], which, depending on other technological factors, is $\rho \mathrm{A}=(8.05$ $8.15) \mathrm{g} / \mathrm{cm} 3$ and is $\approx 97 \%$ of the $\mathrm{x}$-ray density.

According to the results of radiographic studies, in the selected modes of synthesis, the obtained ingots were single-phase, the parameter of the unit cell $\mathrm{a}=6.4591$ (2) $\AA$. The change of this value during powder pressing and annealing of the obtained samples at temperatures of $500{ }^{\circ} \mathrm{C}$ is within the error of the experiment (après+annealing $=6.4589(2) \AA$ ), which may indicate the stability of the defective subsystem under such conditions. In addition, a comparative analysis of the structure of the reflex (220) of the ingot and the pressed PbTe sample (Fig. 2) makes it possible to conclude that there are no differences that could be caused by grinding, pressing or annealing stresses

Due to the polycrystallinity of the samples, the analysis of changes in the unit cell parameter at the level of $0.010 \AA$ is complicated by a number of uncontrolled factors. However, on the other hand, obtaining series of

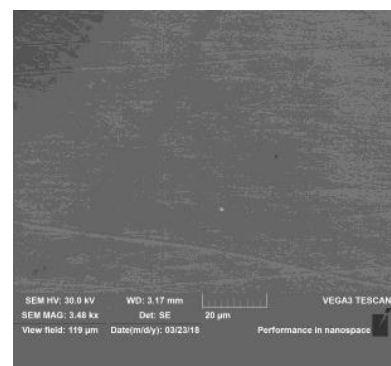

a)

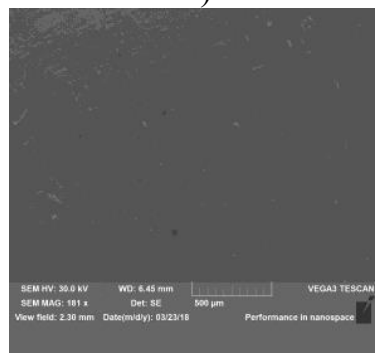

c)

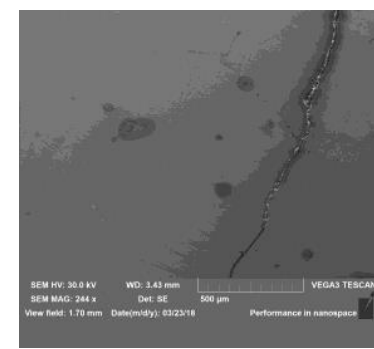

b)

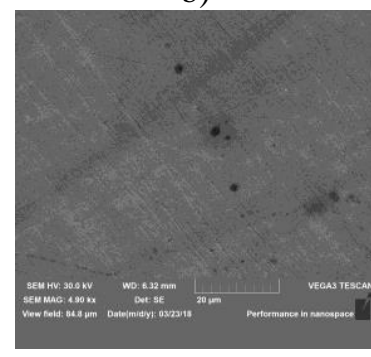

d)
Fig. 1. SEM images of polished and etched surface of ingot $\mathrm{PbTe}(\mathrm{a}, \mathrm{b})$ and pressed at a pressure of $1.5 \mathrm{GPa}$ and annealed at $500^{\circ} \mathrm{C}$ samples of PbTe (c, d).

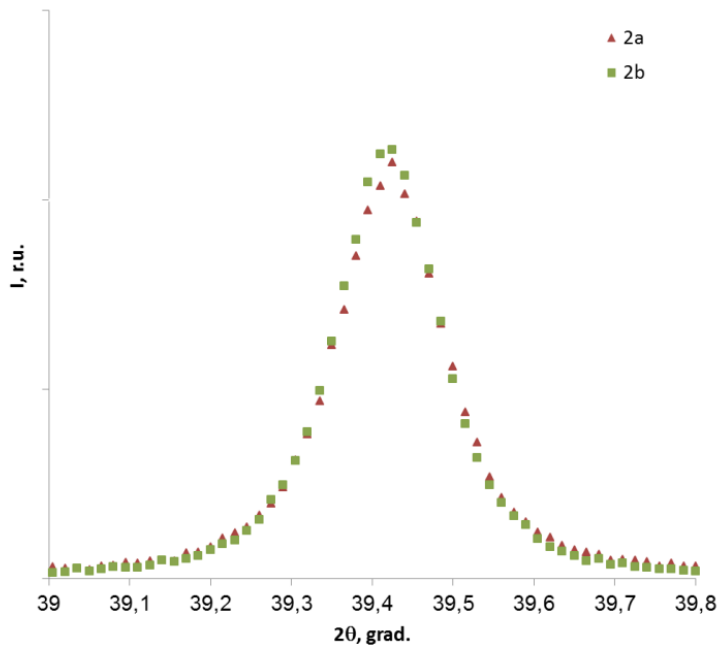

Fig. 2. Comparison of X-ray diffraction reflexes (220) of two samples obtained by the methods: cold pressing in argon and not annealed (2a) and hot pressing in argon at $250{ }^{\circ} \mathrm{C}$ and annealed at $500{ }^{\circ} \mathrm{C}$ (2b).

samples, both in this paper and previous ones [6], with the same parameters within the unit cell, within the errors, may indicate that we still control most of these factors.

The results of measurement of thermoelectric parameters are presented in Fig. 3. It can be seen that qualitative differences in the dependences $\alpha(\mathrm{T}), \sigma(\mathrm{T})$ for the samples obtained by cold pressing in air and hot pressing in argon are not observed (Fig. 3). On the basis of such results, it can be concluded that the p-type conductivity of the samples to a measurement temperature of $250^{\circ} \mathrm{C}$ is caused, probably, by point defects of the crystal lattice, and not by an admixture of oxygen, which could enter the sample at separate stages of its preparation, as was supposed in [7].

Reducing the compression pressure from 2.0 GPa to 
1.5 GPa leads to a decrease in the electrical conductivity throughout the studied temperature range without qualitatively changing the dependence of $\sigma(\mathrm{T})$. As can be seen from Fig. 3, the annealed sample, which was compressed at a pressure of $1.5 \mathrm{GPa}(2 \mathrm{a} *)$, has the same electrical conductivity as the sample obtained at a pressure of $2 \mathrm{GPa}$ and is not annealed (XV 3, XVI 1Sa).

The Seebeck coefficient of annealed specimens slightly depends on the previous conditions of their receipt. For unannealed samples $\alpha(\mathrm{T})$ changes sign at a lower temperature. At the same time, qualitative changes in this dependence are not observed. The thermal conductivity of cold-pressed samples is relatively low. And when using the hot pressing method the coefficient of thermal conductivity is doubled.

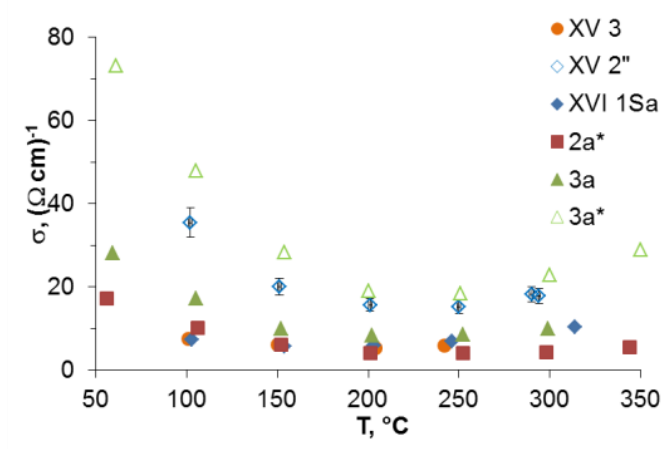

a)

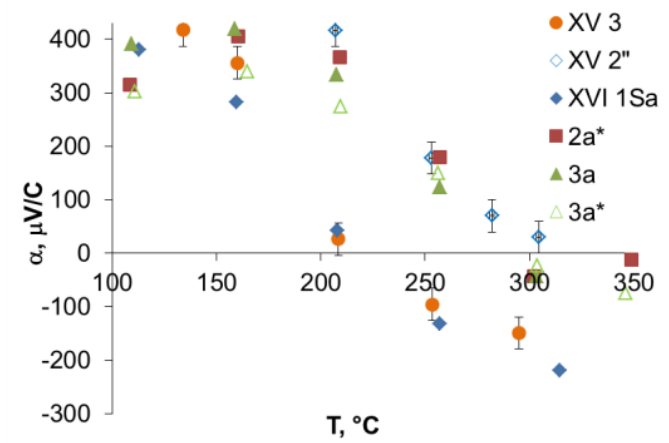

b)

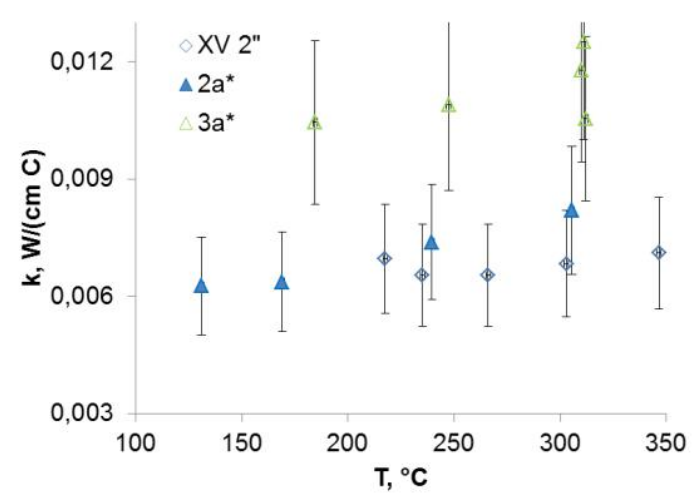

c)

Fig. 3. The temperature dependences of the electrical conductivity $\sigma(\mathrm{a})$, the Seebeck coefficient $\alpha$ (b) and the thermal conductivity $\mathrm{k}$ (b) of the PbTe samples obtained under different technological conditions:XV 3, XVI 1Sa - cold pressing in air (2,0 GPa), unannealed; XV 2* cold pressing in air, annealed at $500{ }^{\circ} \mathrm{C} ; 2 \mathrm{a}^{*}-$ cold pressing in argon $(1.5 \mathrm{GPa})$, annealed at $500{ }^{\circ} \mathrm{C}, 3 \mathrm{a}-$ hot pressing in argon at $250^{\circ} \mathrm{C}(0.5 \mathrm{GPa}), 3 \mathrm{a}^{*}$ - hot pressing in argon at $250^{\circ} \mathrm{C}(0.5 \mathrm{GPa})$, annealed at $500{ }^{\circ} \mathrm{C}$.

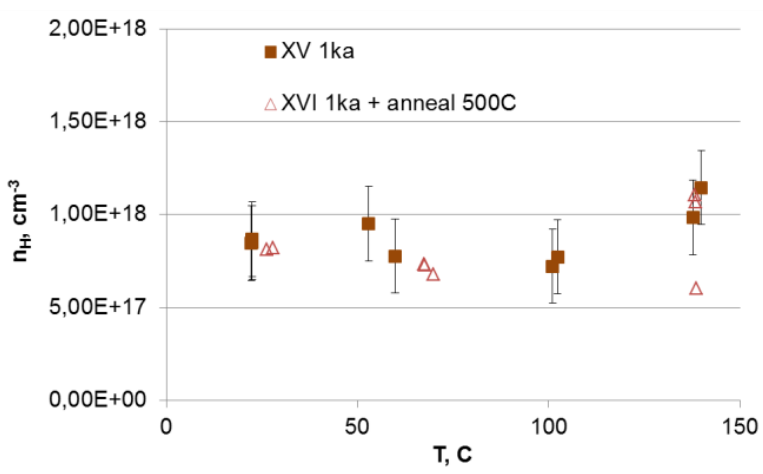

a)

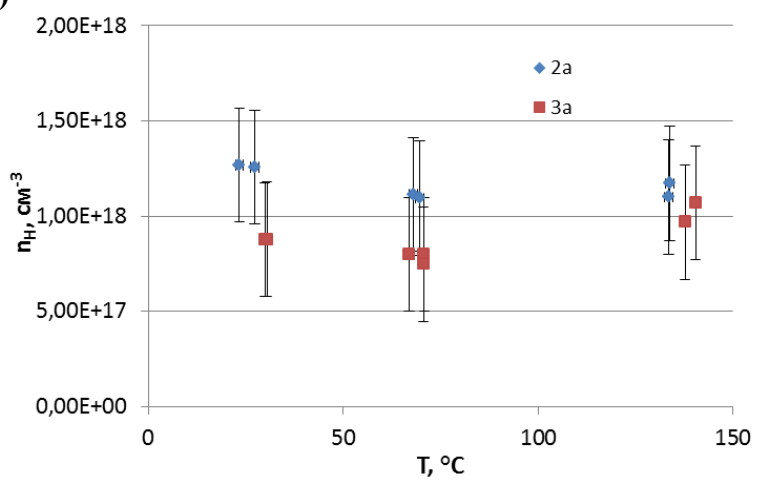

b)

Fig. 4. a - temperature dependences of the Hall concentration of carriers in typical samples pressed at a pressure of $2 \mathrm{GPa}$ (1 ka - unannealed sample, 1 ka+anneal $500{ }^{\circ} \mathrm{C}$ - annealed at $500{ }^{\circ} \mathrm{C}$ sample). b - The dependence of the Hall concentration of carriers on the temperature of cold-pressed and hot-pressed $\mathrm{PbTe}$ samples $\left(2 \mathrm{a}^{*}-\right.$ cold. press. in the air + annealing $500{ }^{\circ} \mathrm{C}$, $3 \mathrm{a}-$ hot press. in argon at $250^{\circ} \mathrm{C}$ ).

Regarding the concentration of carriers, there are some differences in the properties of the samples obtained at compression pressures of 1.5 and 2.0 GPa. Thus, for samples of pressed at higher pressure, the Hall concentration of carriers is $\approx 110^{18} \mathrm{~cm}^{-3}$ regardless of whether or not the sample was annealed (Fig. 4,a). In the case of samples obtained at a pressure of $1.5 \mathrm{GPa}$, annealed samples were always characterized by a concentration of $\approx 1 \cdot 10^{18} \mathrm{~cm}^{-3}$ (Fig. 4,b), whereas in unannealed samples the carrier concentration could vary within $(0.3-1.0) 10 \cdot 18 \mathrm{~cm}^{-3}$, although it was usually in the vicinity of the values characteristic of the annealed specimen.

Thus, regardless of the technological conditions of obtaining the sample (within the variations studied), the concentration of carriers remains constant within an error value of $\approx 110^{18} \mathrm{~cm}^{-3}$. Together with the invariance of the parameter of the unit cell with the same variations of the technological factors of obtaining the sample, we can conclude that the defective subsystem, in particular the concentration of dominant point defects, which determine the numerical value of $\mathrm{n}_{\mathrm{H}}$, does not change. This conclusion requires additional experimental confirmation. But its importance is that the selected technological parameters allow to obtain mechanically stable samples without destroying the defective subsystem formed at higher temperatures during 

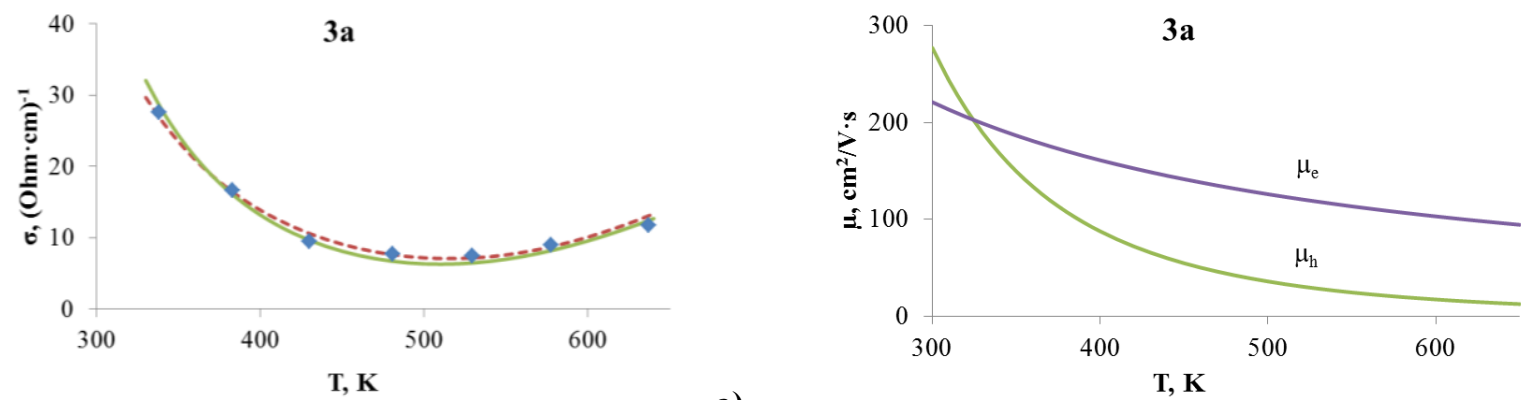

a)

b)
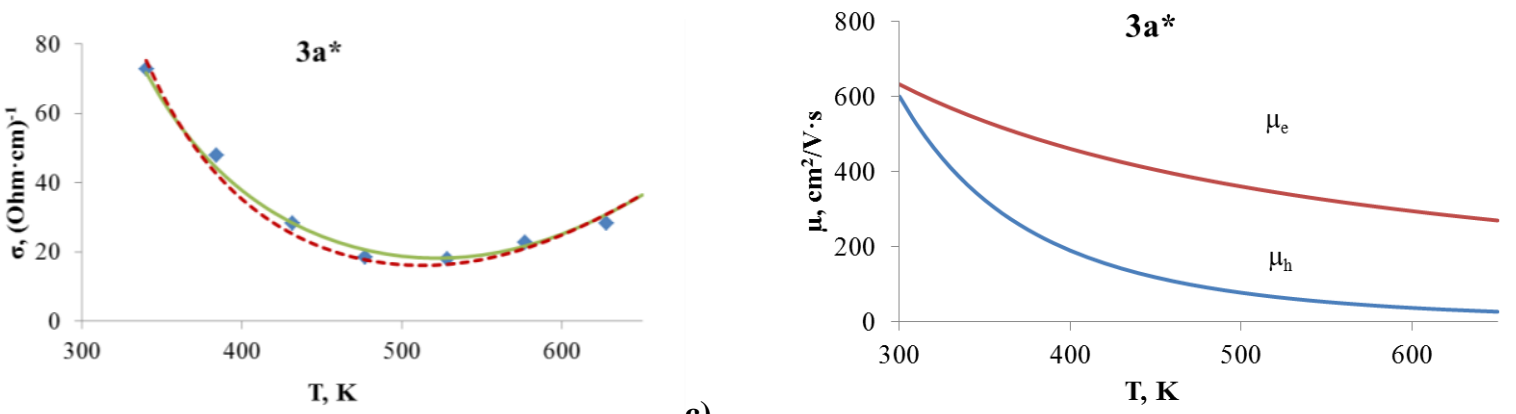

c)

d)
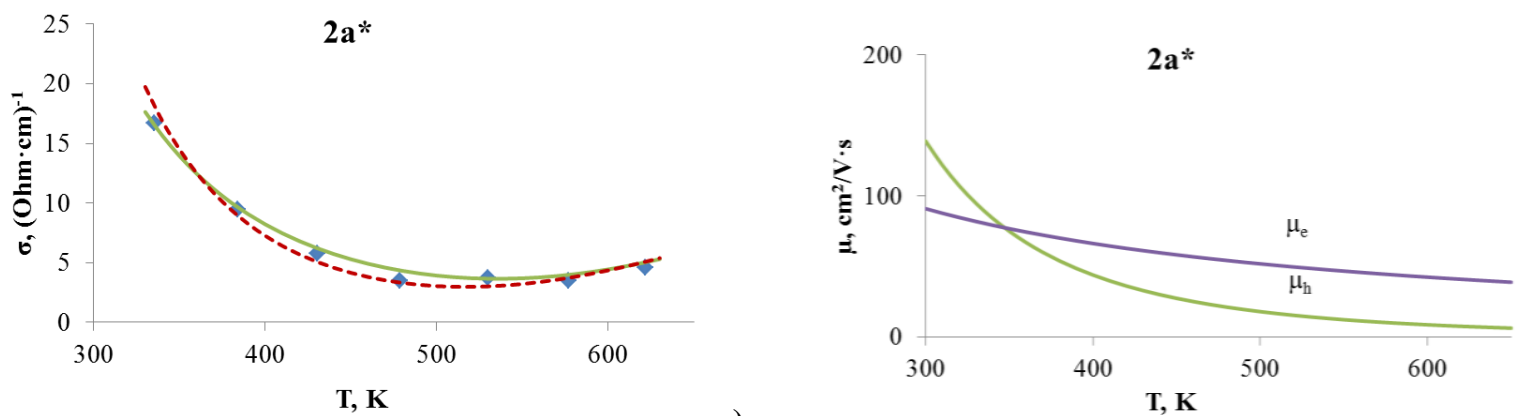

e)

Fig. 5. a, c, e-are the experimental $(\diamond)$ and calculated thermal dependences of the specific conductivity for the samples $\mathrm{PbTe} 3 \mathrm{a}, 3 \mathrm{a} *, 2$ *: solid curve () is calculated using optimal (approximate) parameters; dashed curve (- -) -

calculation for model case $r_{e}=-1.1, r_{h}=-4.0 . \mathbf{b}, \mathbf{d}, \mathbf{f}-$ are calculated for the case of model $r_{e}=-1.1, r_{h}=-4.0$ electron and hole mobility for PbTe $3 \mathrm{a}, 3 \mathrm{a}^{*}, 2 *$ samples.

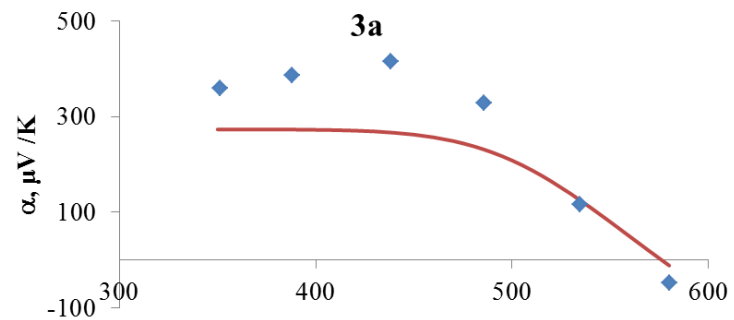

$\mathbf{T}, \mathbf{K}$

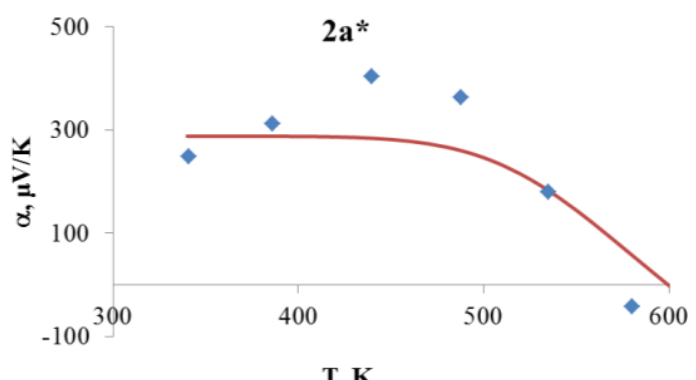

$\mathbf{T}, \mathbf{K}$

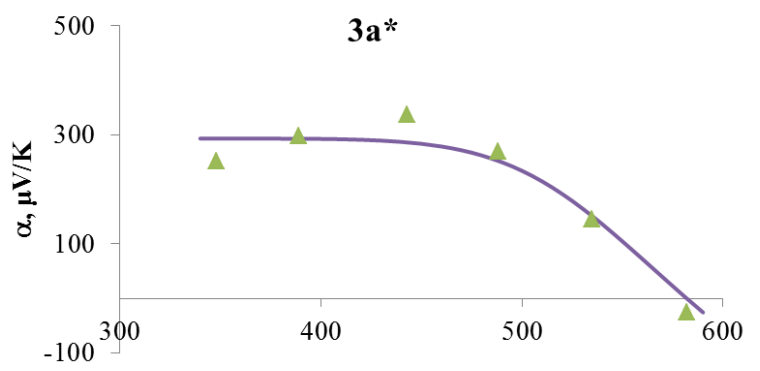

$\mathbf{T}, \mathbf{K}$

b)

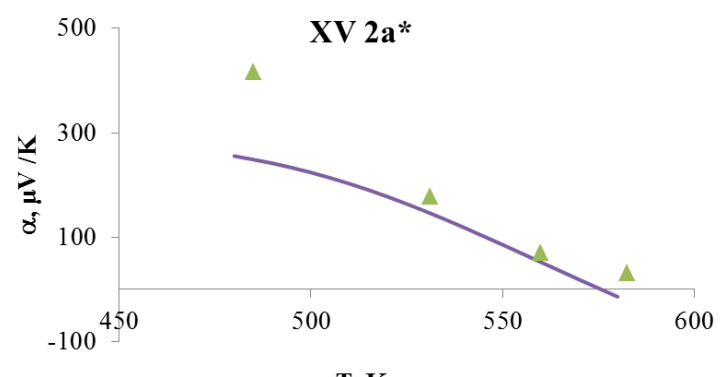

$\mathbf{T}, \mathbf{K}$

d)

Fig. 6. The experimental temperature dependences of the Seebeck coefficient and calculated according to formula (12) for the case of model $\mathrm{r}_{\mathrm{e}}=-1.1, \mathrm{r}_{\mathrm{h}}=-4.0$ for the samples PbTe $3 \mathrm{a}, 3 \mathrm{a} *, 2 \mathrm{a} *$, XV $2 *$. 
crystallization of the ingot.

The immutability of the carrier concentration makes it possible to qualitatively explain the temperature dependence of the Seebeck coefficient increase in the temperature range up to $150{ }^{\circ} \mathrm{C}$. Thus, in the case of nondegeneration of holes up to $150{ }^{\circ} \mathrm{C}$, the Seebeck coefficient will be determined according to the Pisarenko formula [10] $\left(\alpha=\mathrm{k} / \mathrm{e}\left[\mathrm{r}+2+\ln \left(\mathrm{N}_{\mathrm{v}} / \mathrm{p}\right)\right]\right)$. Given the constancy of magnitude $\mathrm{p}$, as well as the fact that $\mathrm{N}_{\mathrm{v}} \sim$ $\mathrm{T}^{3 / 2}$, get $\alpha \sim \mathrm{a}+\mathrm{b} \cdot \ln (\mathrm{T})$. In the case of degeneracy, according [11], $\alpha=8 \pi^{2} \mathrm{k}^{2} /\left(3 \mathrm{eh}^{2} \mathrm{~m}\right) \cdot \mathrm{T} \cdot(\pi / 3 \mathrm{p})^{2 / 3}$. That is, in the first case, we obtain an increase in $\alpha$ with temperature by the logarithmic law, in the second case by a linear one. It is difficult to identify clearly which of the variants is true, since the semiconductor in this case is, in fact, weakly degenerate. Using dependency: $\mathrm{p}=\mathrm{N}_{\mathrm{v}} \exp \left(-\left(\mu+\mathrm{E}_{\mathrm{g}}\right) / \mathrm{kT}\right), \quad$ we will get $-\left(\mu+\mathrm{E}_{\mathrm{g}}\right) / \mathrm{kT}=\ln \left(\mathrm{p} / \mathrm{N}_{\mathrm{V}}\right)$

Here $\mathrm{N}_{\mathrm{v}}=2\left(2 \pi \mathrm{m} * \mathrm{kT} / \mathrm{h}^{2}\right)^{3 / 2}$. At $150{ }^{\circ} \mathrm{C}$ the effective mass of light holes is $\approx 0.15 \mathrm{~m}_{0}$ [12]. At a concentration of $1 \cdot 10^{18} \mathrm{~cm}^{-3}$, the Fermi energy calculated from the ceiling of the valence band is $\approx-0.02 \mathrm{eV}$ and its dimensionless value is $\approx-2$. That is, the holes are slightly degenerate. In the case of heavy holes with effective mass $\approx 1,1 \mathrm{~m}_{0}[13]$, this value will increase about three times, which, qualitatively, the picture will not change.

But the greatest difficulty of analyzing the temperature dependences of $\alpha(\mathrm{T})$ and $\sigma(\mathrm{T})$ is the need to take into account the concentrations of both holes and electrons at temperatures above $150-200{ }^{\circ} \mathrm{C}$. In this case, the observed temperature dependences of the specific conductivity and the Seebeck coefficient can be qualitatively and quantitatively correctly explained on the basis of a model that takes into account two types of carriers (electrons and holes). From a system of two equations:

$$
\begin{gathered}
\mathrm{n}+\mathrm{N}_{\mathrm{a}}{ }^{-}=\mathrm{p} \\
\mathrm{np}=\mathrm{n}_{\mathrm{i}}{ }^{2},
\end{gathered}
$$

we find separately the concentrations of electrons and holes ( $\mathrm{n}$ and $\mathrm{p}$ ), varying only the concentration of ionized $\mathrm{N}_{\mathrm{a}}^{-}$acceptors. Own the concentration $\mathrm{n}_{\mathrm{i}}^{2}$ hope gap width setting under three models: 1) $\mathrm{E}_{\mathrm{g}}=0.38 \mathrm{eB}$ [14], 2) $\left.\mathrm{E}_{\mathrm{g}}=0.18+0.0004 \mathrm{~T}[12], \mathrm{eB}, 3\right)$ dependencies of the first and second models according to the temperature range.

$$
\begin{aligned}
& \mathrm{n}_{\mathrm{i}}{ }^{2}= \mathrm{N}_{\mathrm{v}} \mathrm{N}_{\mathrm{c}} \exp \left(-\mathrm{E}_{\mathrm{g}} / \mathrm{kT}\right), \\
& \mathrm{N}_{\mathrm{c}}=2\left(2 \pi \mathrm{m}_{\mathrm{c}}{ }^{*} \mathrm{kT} / \mathrm{h}^{2}\right)^{3 / 2}, \\
& \mathrm{~N}_{\mathrm{v}}=2\left(2 \pi \mathrm{m}_{\mathrm{v}}{ }^{*} \mathrm{kT} / \mathrm{h}^{2}\right)^{3 / 2}, \\
& \mathrm{~m}_{\mathrm{c}}{ }^{*}= 0,142 \cdot \mathrm{m}_{\mathrm{e}} \cdot(\mathrm{T} / 120)^{0.4}[12], \\
& \mathrm{m}_{\mathrm{v}, \mathrm{l}}{ }^{*}= 0,142 \cdot \mathrm{m}_{\mathrm{e}} \cdot(\mathrm{T} / 120)^{0.4}[12], \\
& \mathrm{m}_{\mathrm{v}, \mathrm{h}}{ }^{*}=1,1 \mathrm{~m}_{\mathrm{e}}[13] .
\end{aligned}
$$

The mobility of electrons and holes is found by expressions:

$$
\begin{gathered}
\mu_{\mathrm{e}}=\mu_{\mathrm{e} 300}(\mathrm{~T} / 300)^{\mathrm{r}_{\mathrm{e}}}, \\
\mu_{\mathrm{h}}=\mu_{\mathrm{h} 300}(\mathrm{~T} / 300)^{\mathrm{r}_{\mathrm{h}}},
\end{gathered}
$$

varying $\mu_{\mathrm{e} 300}$ and $\mu_{\mathrm{h} 300}$ and $r_{\mathrm{e}}$ and $r_{\mathrm{h}}$. Thus, the approximation dependence of the electrical conductivity:

$$
\begin{gathered}
\sigma=\sigma_{\mathrm{e}}+\sigma_{\mathrm{h}}, \\
\sigma_{\mathrm{e}}=\mathrm{en} \mu_{\mathrm{e}}, \\
\sigma_{\mathrm{h}}=\mathrm{ep} \mu_{\mathrm{h}}
\end{gathered}
$$

has four variant parameters are presented in table. 1 . The acceptor concentration varied within the error of the determined Hall concentrations of holes (Fig. 4). The approximation was performed in two steps. In the first one, all five parameters were arbitrarily varied to obtain the best correlation with the experimental data $\sigma(\mathrm{T})$. For samples $3 \mathrm{a}$ and $3 \mathrm{a} *$ these results are shown in Table 1 (parameters in parentheses). It is worth noting that the most satisfactory correlation of the calculated curves $\sigma$ (T) with the experimental ones was achieved in the case of acceptance for the studied temperature range:

$$
\mathrm{E}_{\mathrm{g}}=\text { const }=0.38 \mathrm{eB} \text {. }
$$

The parameters $\mu_{\mathrm{e} 300}$ and $\mu_{\mathrm{h} 300}$ can vary arbitrarily, while re and $r_{h}$ are determined by the scattering

Table 1

The most optimal (in parentheses) are 5 parameters of the approximation of the experimental dependence $\sigma(\mathrm{T})$ and the optimal 3 parameters are fixed at 2, which characterize the scattering of electrons on polar optical phonons, and heavy holes on acoustic ones.

\begin{tabular}{|l|l|l|l|l|l|}
\hline \multicolumn{1}{|c|}{ Sample } & \multicolumn{1}{|c|}{$\mathrm{N}_{\mathrm{a}}^{-}, \mathrm{cm}^{-3}$} & $\mu_{\mathrm{h} 300} \mathrm{~cm}^{2} / \mathrm{V} \mathrm{s}$ & $\mu_{\mathrm{e} 300} \mathrm{~cm}^{2} / \mathrm{V} \mathrm{s}$ & \multicolumn{1}{c|}{$\mathrm{r}_{\mathrm{h}}$} & $\mathrm{r}_{\mathrm{e}}$ \\
\hline $3 \mathrm{a}^{*}$ & $1.23(1.05)$ & $601(811)$ & $633(797)$ & $-4(-4.74)$ & $-1.1(-1.38)$ \\
\hline $3 \mathrm{a}$ & $0.98(0.67)$ & $277(467)$ & $221(129)$ & $-4(-4.7)$ & $-1.1(-0.58)$ \\
\hline $\mathrm{XV3+XVI}$ & 1.21 & 88 & 547 & -4 & -1.1 \\
\hline $\mathrm{XV} 2^{*}$ & 1.2 & 471 & 548 & -4 & -1.1 \\
\hline $2 \mathrm{a}^{*}$ & $1.16(1.11)$ & $139(183)$ & $91(235)$ & $-4(-5.3)$ & $-1.1(-2.06)$ \\
\hline
\end{tabular}

Table 2

Mobility temperature dependence parameters and thermo-EMF coefficient for different scattering mechanisms [10]

\begin{tabular}{|l|c|c|c|c|c|}
\hline \multicolumn{1}{|c|}{ Scattering on: } & $\mathrm{r}$ & $\mathrm{t}$ & $\mathrm{r}_{\mathrm{h}}$ & $\mathrm{r}_{\mathrm{e}}$ & $\mathrm{A}=2+\mathrm{r}$ \\
\hline optical phonons (polar scattering) & 1 & $3 / 2$ & -2 & -1.1 & 3 \\
\hline optical phonons (deformation potential) & 0 & $3 / 2$ & -4 & -2.5 & 2 \\
\hline acoustic phonons & 0 & $3 / 2$ & -4 & -2.5 & 2 \\
\hline short-term potential & 0 & $1 / 2$ & -3 & -1.5 & 2 \\
\hline Coulomb potential & 2 & $1 / 2$ & +1 & 1.3 & 4 \\
\hline
\end{tabular}


mechanism. The temperature dependence of the conductivity will be determined by the temperature dependence of the mobility, which can be represented as [10]:

$$
\mu \sim \mathrm{m}^{*}(\mathrm{~T})^{\mathrm{r}-3 / 2-1} \mathrm{~T}^{\mathrm{r}-\mathrm{t}} .
$$

$\mathrm{m}^{*}$ - effective mass, $\mathrm{r}$ - carrier scattering parameter $(\mathrm{r}-$ a parameter that depends on the scattering mechanism: $r$ $=0$ when scattered on acoustic phonons, the strain potential of optical phonons, and the short-run potential of point defects; $r=1$ when scattered on polar optical phonons; $r=2$ when scattered on ionized impurities (Coulomb potential)), $\mathrm{t}=1 / 2$ for short-range potential and ionized impurities, $\mathrm{t}=3 / 2$ for acoustic phonons, polar and deforming optical phonons. Given that the effective mass of light holes, like electrons, is also a function of temperature $\left(\mathrm{m} \sim \mathrm{T}^{0,4}[12]\right)$, then dependence (9) can be represented as:

$$
\mu_{\mathrm{e}}=\mathrm{T}^{(\mathrm{r}-3 / 2-1) 0.4+\mathrm{r}-\mathrm{t}}=\mathrm{T}^{\mathrm{r}_{\mathrm{e}}}
$$

In the case of heavy holes, the effective mass is independent of temperature. Then

$$
\mu_{\mathrm{h}}=\mathrm{T}^{(\mathrm{r}-3 / 2-1)+\mathrm{r}+\mathrm{t}}=\mathrm{T}^{2 \mathrm{r}-5 / 2-\mathrm{t}}=\mathrm{T}^{\mathrm{r}_{\mathrm{h}}}
$$

The calculated values of the degree index for different mechanisms are presented in Table. 2.

Comparing the data in the table 1 for samples $3 \mathrm{a}$ and $3 \mathrm{a} *$ with the data of table. 2 , we can conclude that the most probable mechanisms of electron scattering are scattering on polar optical phonons $\left(\mathrm{r}_{\mathrm{e}}\right.$ (aprox) $\approx$ $-0.58(-1.38), \mathrm{r}_{\mathrm{e}}$ (theor) $\left.=-1.1\right)$. In the case of holes, the degree of the degree of the approximation determined by the approximation $\approx-4.7$ can be obtained only on condition that the influence of heavy holes is decisive in the formation of mobility. In this case, $\mathrm{r}_{\mathrm{h}}$ (theor) $=-4.0$ and the scattering is carried out on acoustic phonons or deformation potential of optical phonons. Such a conclusion is completely consistent with the conclusion made in previous work [7] and [8]. An additional argument to support the decisive role of heavy holes is that the best correlations of the calculated data with the experiment are obtained provided that the bandwidth is $0.38 \mathrm{eV}$ and does not change with temperature.

From the analysis of the numerical values of $\mu_{\mathrm{e} 300}$ and $\mu_{\mathrm{h} 300}$ we can conclude that the motions in the samples obtained by cold pressing at a pressure of $2 \mathrm{GPa}$ and hot pressing at $\mathrm{T}=250{ }^{\circ} \mathrm{C}$ are almost identical. Given the much lower values of the thermal conductivity of cold-pressed specimens, it can be considered that the high-pressure cold-pressing method is promising in terms of improving the thermoelectric figure of merit of $\mathrm{PbTe}$ based materials.

With certain mechanisms of carrier scattering, it is possible to calculate the temperature dependence of the Seebeck coefficient:

$\alpha=-\mathrm{k} / \mathrm{e}\left[\mathrm{A}_{\mathrm{e}} \sigma_{\mathrm{e}}-\mathrm{A}_{\mathrm{h}} \sigma_{\mathrm{h}}+\sigma_{\mathrm{e}} \ln \left(\mathrm{N}_{\mathrm{c}} / \mathrm{n}\right)-\sigma_{\mathrm{h}} \ln \left(\mathrm{N}_{\mathrm{v}} / \mathrm{p}\right)\right] / \sigma$,

where the constants $A_{e}\left(A_{h}\right)$ are dependent on the charge carrier scattering mechanism $(A=r+2$, tab. 2). The results of calculating $\alpha(\mathrm{T})$ are presented in Fig. 6 . In the temperature range up to $450 \mathrm{~K}$, there is a certain difference between the calculated curve $\alpha(\mathrm{T})$ and the experimental data. At the same time, for higher temperatures the correlation with the experiment is satisfactory. Obviously, the proposed model adequately characterizes the electronic subsystem (scattering mechanism, temperature dependence of the effective mass), and the influence of additional factors is possible for holes. Their manifestation may be due to the complex structure of the valence band in the temperature range of $\approx 450 \mathrm{~K}$ and, probably, additional scattering mechanisms, in particular, as noted in [7], scattering at grain boundaries. It should also be borne in mind that the formula used for the Seebeck coefficient is valid for the non-degenerate case, whereas the test specimens at the indicated temperatures are slightly degenerate.

\section{Conclusions}

1. The specific conductivity and Seebeck coefficient, in the samples obtained by hot pressing at a pressure of $0,5 \mathrm{GPa}$ and $\mathrm{T}=250{ }^{\circ} \mathrm{C}$ and cold pressing at a pressure of $2 \mathrm{GPa}$, are almost the same, which, with a lower coefficient of thermal conductivity of cold-pressed samples, determines the prospectivity of obtaining materials with high quality.

2. It is established that the dominant mechanism of electron scattering in powder PbTe samples obtained by powder compression is scattering on polar optical phonons and holes on acoustic phonons. Moreover, such a pattern is preserved for all the samples tested obtained by various technological factors.

3. Investigation of the unit cell parameter, the measurement of the Hall carrier concentration and the modeling of the electrophysical properties of the samples obtained under different technological conditions indicate slight changes in the defective subsystem (concentrations of dominant point defects) at the investigated pressing and annealing temperatures, which are important factors predefined properties of thermoelectric materials. That is, the defective material subsystem, and therefore the concentration of free charge carriers in it, can be formed at a separate stage of thermocouple creation, even before carrying out technological operations of briquetting.

Saliy Ya.P. - Professor, Doctor of Physical and Mathematical Sciences, Professor of the Department of Physics and Chemistry of Solids;

Matkivskyi O.M. - Ph.D (Physics and Mathematics), Senior Researcher of the Department of Physics and Chemistry of Solids;

Horichok I.V. - Ph.D (Chemistry), Professor of the Department of Physics and Chemistry of Solids. 
[1] L.-D. Zhao, V. P. Dravid, M. G. Kanatzidis, The panoscopic approach to high performance thermoelectrics, Energy Environ. Sci. 7, 251-268 (2014) (https://doi.org/10.1039/C3EE43099E).

[2] J.R. Sootsman, D. Y. Chung, M. G. Kanatzidis, New and Old Concepts in Thermoelectric Materials, Angew. Chem. Int. Ed. 48, 8616-8639 (2009) (https://doi.org/10.1002/anie.200900598).

[3] A.V. Dmitriev, I.P. Zvyagin, Sovremennyie tendentsii razvitiya fiziki termoelektricheskih materialov, UFN, 180(8), 821-838 (2010).

[4] H. Wang, J.-H. Bahk, Ch. Kang, J. Hwang, K. Kim, J. Kim, P. Burke, J. E. Bowers, A. C. Gossard, A. Shakouri, W. Kim, Right sizes of nano- and microstructures for high-performance and rigid bulk thermoelectrics, PNAS 111(30), 10949-10954 (2014) (https://doi.org/10.1073/pnas.1403601111).

[5] E. P. Sabo, Tehnologiya halkogenidnyih termoelementov. Fizicheskie osnovyi. Journal of Thermoelectricity 3, 30-46 (2000).

[6] I.V. Horichok, I.M. Lishchynskyi, S.I. Mudryi, O.S. Oberemok, T.O. Semko, I.M. Khatsevych, O.M. Matkivskyi, H.D. Mateik, R.O. Dzumedzei, Tekhnolohichni aspekty otrymannia termoelektrychnoho PbTe, Sensorna elektronika i mikrosystemni tekhnolohii 14(3), 53-64 (2017).

[7] I.V. Horichok, V.V. Prokopiv, R.I. Zapukhlyak, O.M. Matkivskyj, T.O. Semko, I.O. Savelikhina, T.O. Parashchuk, Effects of Oxygen Interaction with PbTe Surface and Their Influence on Thermoelectric Material Properties, Journal of Nano- and Electronic Physics 10(5), 05006(5pp) (2018) (https://doi.org/10.21272/jnep.10(5).05006).

[8] M.Y. Vynohradova, V.Y. Tamarchenko, L.V. Prokofeva, Parametryi slozhnoi valentnoi zonyi y osobennosty provodymosty v r-PbTe, FTP, 9(3) (1975).

[9] D.M. Zayachuk, The dominant mechanisms of charge-carrier scattering in lead telluride, FTP 31(2), 217-221 (1997) (https://doi.org/10.1134/1.1187322).

[10] B.M. Askerov, Elektronnyie yavleniya perenosa v poluprovodnikah, Nauka, 320 p. (1985).

[11] G. J. Snyder and E. S. Toberer, Complex thermoelectric materials, Nature materials 7, 105-114 (2008) (https://doi.org/10.1142/9789814317665 0016).

[12] B.M. Askerov, Elektronnyie yavleniya perenosa v poluprovodnikah, Nauka, 320 p. (1985).

[13] B.F. Gruzinov, I.A. Drabkin, G.F. Zaharyugina et el. Polozhenie urovnya Fermi v splavah PbTe, legirovannyih primesyu In, v oblasti vyisokih temperature, FTP, 13(2), 330-334 (1979).

\title{
Я.П. Салій, О.М. Матківський, І.В. Горічок \\ Механізми розсіювання носіїв у пресованому $\mathrm{PbTe}$
}

\author{
Прикарпатський національний університет імені Василя Стефаника, Івано-Франківськ, Украӥна, е-таіl: \\ o.matkivsky@opora.org.ua
}

\footnotetext{
Представлено результати досліджень структурних та термоелектричних властивостей отриманих методом пресування порошку зразків РbTe. Для інтерпретації отриманих результатів проведено теоретичний розрахунок питомої електропровідності та коефіцієнту термо-ЕРС на основі моделі, що враховує два типи вільних носіїв заряду. Зроблено висновки про механізми розсіювання носіїв.

Ключові слова: плюмбум телурид, термоелектричні властивості, механізми розсіювання.
} 